\title{
Motivations for tourism adoption by vineyards worldwide: A literature review
}

\author{
M.C. Borges and D.C. de Menezes \\ Federal University of Rio Grande do Sul - Av. Bento Gonçalves, 7712 Porto Alegre, Brazil
}

\begin{abstract}
Wine tourism has been increasingly implemented by wineries in several countries around the world. This article aims at identifying the motivations for wine tourism adoption by wineries around the world through a narrative bibliographic review. This paper includes an analysis of articles related to the subject taken from the Web of Science database. In this article, we identified the objectives, methods, and conclusions reached by authors, who researched wine tourism. The bibliographic survey based on the keywords "wine" and "tourism", resulted, after refining it by reading titles and abstracts, in 20 articles. The results show that most wineries in the studied sample adopt wine tourism as a strategy to achieve marketing-related benefits. Also, some wineries are motivated by the competitive advantage, economic development and increasing demand for such service. It is concluded that wineries are increasingly seeking to adapt to current consumer demands. From the perception of the importance of service experience offered to the consumer, mainly in the product sale.
\end{abstract}

\section{Introduction}

The wine sector is being studied under different perspectives in the academic world; however, concerning the tourism perspective an interest for further studies on this subject awakened as of the year 2000 [1]. Every year, millions of tourists travel to Europe and other wine regions such as Australia, New Zealand, the United States, South Africa and Latin America [2].

Tourism is an activity that has stood out in recent decades because it is a product that can only be consumed on the spot, and has been considered necessary in the local development of the regions in which it occurs [3]. Segmented tourism emerges alongside the development of new proposals and destinations, in which wine tourism is found (enotourism). Wine tourism is characterized by the delocalization motivated by the interest in getting to know wine-producing regions [4].

In European countries, considered "the old world" when it comes to wine, the relationship between tourism and the beverage is already considered a tradition. These countries perceived that the association between these two chains showed potential regarding economic and social development as well as wine heritage [5] and added value to enable new consumer experiences. Thus, this study proposes to answer the following question: Why do winemakers adopt wine tourism? This question arises from the fact that winemakers are increasingly investing in tourism, but it is essential to know their motivations for this adoption.

\section{Theoretical background}

Wine tourism had its first research phase in the 1990s since the first conference on the subject was held in Australia (1998). This first conference focused on justifying and better understanding the dimensions of the emerging subfield [6].

Due to competitiveness, some products such as still and sparkling wine were associated with specific territories, with regional brands and certification of origin. Some regions organized themselves into productive clusters and specialized in particular products based on this structure [7]. The concept of wine tourism, even today, is not uniform, due to the many approaches to defining it. When based on the marketing approach, most of the definitions are set on motivations and experiences related to wine potentials and tourists [6]. Also, wine tourism can also be considered as the visit of vineyards, wineries, wine festivals or grape shows in which the primary motivation for tourists is related to wine tasting and the attributes of a wine region [8].

Taking other elements into consideration wine tourism can be: [....] segment of the tourist phenomenon, which involves the movement of people, motivated by the organoleptic properties and by the whole context of wine tasting and production, as well as the appreciation of traditions, culture, gastronomy, landscapes and the typical characteristics of the regions producing grapes and wines. It is a phenomenon endowed with subjectivity, whose main substance is the encounter with those who produce grapes and wines [9].

Still, on the existing theories within wine tourism, the different perceptions related to wine tourists' motivations are noteworthy. If on the one hand there are those who defend that its primary motivation is the wine, its tasting, celebrations, and grape growing [8]. On the other hand, Johnson (1988) apud [8], infers that the particular landscape of the vineyards and the search for leisure through wine, in recreation not directly involving the consumption of the drink, also defines the motivation for the enotourist. 
For a destination to be attractive to tourists, it is necessary to have the support and infrastructure to receive and provide expected services. Wine is considered the central product of both the wine and the wine tourism industry. Some services are considered essential for increasing benefit perception by tourists, such as tasting, courses and lectures, customer service, wine clubs, wine tours, as well as the attributes of wine and the landscape [10].

In addition to the services considered basic, enotourism also offers complements as recreation and relaxation, entertainment and events, as well as hospitality and other typical tourism services (such as lodging and transportation) [10].

In this context, it is possible to perceive that the growth of the tourism is associated, to a large extent, to the sum of the wine products to other tourist attractions and of diffusion [1]. Moreover, in the world scenario [11], states that the number of segments in the "old world" countries, such as France, and in "new world" countries such as South Africa was made possible by the combination of activities gastronomic tourism, ecotourism and rural tourism in wine producing regions.

As of the 1950s, with the technological and scientific evolution, some European countries began to perceive the dimension of tourism and began to take advantage of its cultural and infrastructural characteristics in the search for greater competitiveness in the market. Tourism, therefore, has become one of the pillars of the international scenario [9].

Wine tourism development, therefore, requires not only the infrastructure of grape growing but also additional services related to wine and other activities, sometimes not related as much. The enotourist looks for an experience that goes beyond the core offered by the wine industry; the enotouristic consumption expects to feel and perceive the local culture, from other products, costumes, and gastronomy. Also, wine tourists are also looking for attracting destinations, in the landscape and climate, as well as to obtain information [6]. These perceived items demonstrate the magnitude of the wine tourism, the complexity of its services and the impact of its changes, once it involves different sectors and activities to generate an experience that the tourist will consider valid.

If, on the one hand, there is the highest perception of benefits related to the negative impact caused by tourism, on the other hand, since 1990 the negative impact has also begun to be studied, including inhabitants of the regions visited in the research [12].

Therefore, the development of wine tourism was studied taking into consideration the companies involved in the business, the tourists, the inhabitants of the tourism regions and other elements involved as control and regulation agents of the sector, as well as incentive foundations, among others.

\section{Method}

The objective of this study is to identify the motivations for the adoption of wine tourism by winemakers. To achieve this objective, a bibliographic review was carried out. The method consisted of analyzing objectives, methods, studied segments and conclusions of papers published in the Web of Science database. This method allowed us to analyze what has been produced in the world about wine tourism.

Initially, 391 texts were found regarding the subject using the words "wine" and "tourism." To refine the selection, the titles and summaries of the papers found were read. The reading process allowed the identification of 20 articles that were relevant to this research. An Excel file was used for the recording of the articles for their analysis. After that, a full reading was done.

The analysis of the data was carried out from the data bank generated in Excel, resulting in some tables and charts for the presentation of the sample.

\section{Results and analyses}

In order to meet the proposed objective, this study gathered articles published in the Web of Science database. The data were published until December 2017, regarding the theme of wine tourism.

Twenty articles were selected, which indicated some motivation on the part of winemakers to adopt the wine tourism strategy. The selected articles are listed in Table 1.

Then, we wanted to know more about the selected sample. Therefore, a table was elaborated according to each selected year, as well as the various sources and the number of articles published by year (Table 2).

Wine tourism has grown continuously in the last 50 years, becoming one of the fastest growing economic sectors in the world [13]. There is still, however, a debate about its benefits for winemakers and the environment by Hall (1996) apud [14].

The definition of wine tourism most cited in the articles is that of Hall (1996) apud [14]: Wine tourism can be defined as visits to vineyards, wineries, wine festivals and wine shows where a tasting of grape wines and experiencing the attributes of a grape wine region are the main motivating factors for visitors.

On the other hand, the definition of [15]complements the previous definition with other services and experiences, making it broader and more complete: Wine tourism is, therefore, the offer of goods and services that are not only associated with wineries and canteens, but also with all the businesses involved with wine and tourist activities, including the means of accommodation, transport, tours, tourist guides and drivers, gift vouchers and agreements, among other services. From these analyses, it is possible to see all the involvement and commitment of the wine tourism with the tourist enterprises in general.

Previous studies have shown the characteristics of the tourist services' consumers, their choices regarding destinations and the motivations that bring these tourists to certain places. It is, in the meantime, essential to identify the motivations of the winemakers to adopt the wine tourism strategy, since the implementation of this service demands some investment. Therefore, considering Table 3, it is possible to identify the apparent motivations in the articles analyzed.

The winemakers presented various motivations for the adoption of wine tourism. However, in the sample of articles studied, most of the articles presented some motivation related to marketing. [16] present wine tourism as a form of consumer experience, bringing direct sales and relationship to the consumer. Wine tourism is increasingly associated with marketing, which is an important strategy 
Table 1. Analyzed articles and their respective authors.

\begin{tabular}{|c|c|}
\hline Title & Authors \\
\hline $\begin{array}{l}\text { Bibliometric analysis of publications } \\
\text { on wine tourism in the databases Scopus and WoS }\end{array}$ & $\begin{array}{c}\text { Amador Durán Sánchez, María de la Cruz Del Río Rama, } \\
\text { José Álvarez García }\end{array}$ \\
\hline $\begin{array}{l}\text { City, architecture, and wine: Wine tourism in the } \\
\text { contemporary society }\end{array}$ & $\begin{array}{l}\text { Douglimar Meireles de Oliveira, Antonio Ferreira } \\
\text { Colchete Filho }\end{array}$ \\
\hline $\begin{array}{l}\text { Combining Wine production and Tourism. } \\
\text { The Aeolian Islands }\end{array}$ & $\begin{array}{c}\text { Agata Nicolosi, Lorenzo Cortese, Francesco Saverio } \\
\text { Nesci, Donatella Privitera }\end{array}$ \\
\hline $\begin{array}{l}\text { Competitive advantages of firms in agro-industrial } \\
\text { clusters: Study of wine in Brazil and Chile }\end{array}$ & $\begin{array}{c}\text { Adilene Alvares Mattia, Janaina Macke, Janete Sttofel, } \\
\text { Daniel Miranda Sala }\end{array}$ \\
\hline $\begin{array}{l}\text { Competitive and innovation factors } \\
\text { in wine tourism clusters: A comparative study between } \\
\text { consolidated and emerging regions in Brazil and Uruguay }\end{array}$ & $\begin{array}{c}\text { Shana Sabbado Flores, Claudio Farias, Gabriel Andrade, } \\
\text { Maria Teresa Russi }\end{array}$ \\
\hline $\begin{array}{c}\text { Food and Wine Tourism: an Analysis of Italian } \\
\text { Typical Products }\end{array}$ & Olivieri, F.M.; Giraldi, A. \\
\hline Food and wine tourism in Basilicata & $\begin{array}{l}\text { Angelo Bencivenga, Paloma Dalterio Vollaro, } \\
\text { Francesco Forte, Anna Maria Giampietro, Annalisa Percoco }\end{array}$ \\
\hline Food and Wine Tourism as a Pull Factor for Tuscany & Lemmi, E.; Siena Tangheroni, M. \\
\hline $\begin{array}{l}\text { Heritage, vineyard, and tourism: specific resources to } \\
\text { innovate the territorial development of } \\
\text { Castilla - La Mancha }\end{array}$ & $\begin{array}{c}\text { Julio José Plaza Tabasco María del Carmen Cañizares } \\
\text { Ruiz Ángel Raúl Ruiz Pulpón }\end{array}$ \\
\hline $\begin{array}{l}\text { Historical and Cultural Wine Heritage on Northwest } \\
\text { Portugal as Touristic Resource }\end{array}$ & Gonçalo Nuno Ramos Maia Marques, José Maia Marques \\
\hline $\begin{array}{l}\text { Participatory strategy analysis: The case of wine } \\
\text { tourism business }\end{array}$ & $\begin{array}{l}\text { Giuseppina Carrà, Mariagiulia Mariani, } \\
\text { Ivana Radić, Iuri Peri } \\
\end{array}$ \\
\hline $\begin{array}{l}\text { Service quality evaluation in the perception of the wine } \\
\text { tourist with Fuzzy Logic and Ideal Solutions }\end{array}$ & $\begin{array}{l}\text { Joao Batista de Freitas, Juan Carlos Martín, } \\
\text { Concepción Román }\end{array}$ \\
\hline $\begin{array}{c}\text { Sustainable Mountain Tourism: An Analysis of } \\
\text { Bosnia-Herzegovina's Wine Tourism and its Future }\end{array}$ & John Hudelson \\
\hline The Prospect and Forecast of China's wine tourism in 2011 & Han Lirong \\
\hline $\begin{array}{l}\text { The wine, as a tourist resource for the promotion of local } \\
\text { development. an opportunity for the region of Vinalopo } \\
\text { (Alicante) and the highlands Yecla-Jumilla (Murcia) }\end{array}$ & Antonio Martínez Puche, Francisco José Morales Yago \\
\hline $\begin{array}{l}\text { Unpacking the geography of tourism innovation in } \\
\text { Western Cape Province, South Africa }\end{array}$ & Irma Booyens, Christian M. Rogerson \\
\hline $\begin{array}{l}\text { Wine tourism and destination management organizations: } \\
\text { international case studies }\end{array}$ & $\begin{array}{l}\text { Alba Fernández Alonso, Lola Herrero Amo, } \\
\text { José Antonio Vidal }\end{array}$ \\
\hline Wine tourism and sustainable environments & Ms. Luisa González San José \\
\hline $\begin{array}{l}\text { Wine tourism in Baja California, Mexico: An analysis of } \\
\text { its supply and a comparison with the wine region of } \\
\text { La Rioja, Spain. }\end{array}$ & Lino Meraz Ruiz, Agustín V. Ruiz Veja \\
\hline $\begin{array}{l}\text { Wine tourism: opportunities and challenges for regional } \\
\text { tourism development in the wine region of the } \\
\text { Sao Francisco Valley - Northeast Brazil }\end{array}$ & $\begin{array}{c}\text { Paula Wabner Binfare, Patrícia Lins de Arroxelas Galvão, } \\
\text { Cleber Augusto Trindade Castro }\end{array}$ \\
\hline
\end{tabular}

Source: Created by the author, according to the articles filtered in the WoS database.

for the development of the wine industry. Even in countries where wine production is a tradition, winemaking is a strategy to restrict the relationship with the consumer $[16,17]$ present wine tourism as an opportunity linked to distribution, arguing that it is mainly an opportunity for small producers - wine tourism eliminates the need for intermediaries, increasing margins, and facilitates marketing since small businesses typically face greater difficulty in finding their way into the market. Furthermore, they draw attention to the infrastructure and the need for higher investments, which may be an initial difficulty for entry into the wine tourism business.

The wineries inserted in regions where there are an active organization, routes, and associations, also present motivations for the adoption of wine tourism. [...] the
Wine Routes are established to build and/or consolidate a reputation for quality in a wine region [...] [18]. Thus, the reputation can be one of the motivations regarding the adoption of a wine tourism strategy, since the winemakers who choose to participate in this process must agree with it. For [15], the attraction of tourism related to winemaking can be related to the improvement of the image of the wines offered by a company. Therefore, it is an opportunity to show the tourist the quality of a company's products and to link this quality image to the region where it belongs: Thus, the image of the products offered during the visit is perceived by means of an intrinsic meaning to the visited region [15]. Another apparent motivation in a sample of articles was competitive advantage. [19] comment on the addition of wine tourism to the already consolidated 
Table 3. Motivations for winemakers to add wine tourism $X$ quantity of articles.

\begin{tabular}{|l|c|}
\hline Motivations & Quant. articles \\
\hline Marketing & 5 \\
\hline Competitive advantage & 3 \\
\hline Other/unspecified & 3 \\
\hline $\begin{array}{l}\text { Perception of growing demand } \\
\text { for cultural tourism/Strengthening } \\
\text { tourism }\end{array}$ & 1 \\
\hline Offer Qualification & 1 \\
\hline $\begin{array}{l}\text { Strengthening of the cultural } \\
\text { identity of the product }\end{array}$ & 1 \\
\hline Sustainable development & 2 \\
\hline $\begin{array}{l}\text { Local development/economic } \\
\text { development }\end{array}$ & 1 \\
\hline Clusters & 1 \\
\hline $\begin{array}{l}\text { Increase the consumption of } \\
\text { local wine }\end{array}$ & \\
\hline \begin{tabular}{l} 
Created by the author, according to the articles filtered in the WoS \\
\hline
\end{tabular} & \\
\hline
\end{tabular}
database.

gastronomic tourism and complement the importance of considering the growing agricultural tourism. [20] affirm that some key-factors are capable of promoting and broadening the market, drawing competitive advantages for wine tourism. They are landscape, cultural heritage, rural lifestyle, richness in typical and quality agricultural products and brands of products and territorial brands.

De [21] added the importance of improvements in services to the debate, to guarantee better business performance and increase competitiveness.

Moreover, the growing demand for cultural tourism was one of the most important aspects of the adoption of tourism according to [22]. The addition of wine and gastronomic tourism as primary activities and not as secondary is one of the ideas pointed by the authors.

The qualification of the offer was one of the motivations found in the sample studied [23] affirm that for some winemaking companies there is no study of the architecture, history, and culture of their region and property so that they can present the most qualified information and experience to tourists.

[24] increment the discussion, saying that the image of wine or food is not enough to bring a tourist to choose a particular tour operator, but rather to link this image of the product to the culture of the region could be a solution for this.

According to [25], wine-related tourism brings out other aspects such as economic, social and environmental, as it is an activity carried out through the culture of wine and the experience that this service provides. Wine tourism is a form of pleasant pleasure around wine and its culture, which is a reflection of wine use of the environment and its impact on the social and economic development of regions [25]. Therefore, for the author, the wine tourism is directly related to sustainability and sustainable development.

The local development is a motivation presented by [26] for the adoption of wine tourism by some winemakers. Since it is a service that takes place in a particular place and involves the consumption of products from the region itself, the authors believe that wine 
tourism generates wealth. Wine tourism implies a joy of local products and is always established as a more general experiential tourism. Landscapes, environments, architectural constructions (traditional or more avantgarde), local gastronomy, are resources that play a fundamental role in the appreciation of tourists [26].

Economic development, according to [27], is an important motivation for exploring wine tourism. The generation of employment and income traced by this activity is important for the regions where tourism takes place. Also, wine tourism generates experience and makes it possible for tourists to get to know a region and appreciate its products.

Another motivation was the participation of clusters. The strategic advantages provided by being part of a cluster related to wine tourism are so clear that many wineries decide to take part in it. In [17], the authors sought to identify innovations in the wine tourism sector based on geographical clustering.

Finally, the last motivation found in the exhibition was the low production cost. [28] presents wine tourism as a business opportunity in regions where the production cost of wine and the available labor force are cheap, and whose landscapes attract tourists. According to this author, financial support and partnerships for investment in infrastructure are essential.

The articles classified in the category other/unspecified are those that, although part of the sample, do not present aspects that could be identified as motivations for the winemakers to adopt the wine tourism strategy.

\section{Conclusions}

The objective of this study was to identify the motivations for the adoption of wine tourism by winemakers. A bibliographic study was carried out analyzing 20 articles regarding wine tourism to identify these motivations.

From this analysis, it was possible to identify the reasons that led the wineries to choose to add tourism services related to wine. Among them are Marketing, competitive advantage, perception of growing demand from cultural tourism/ strengthening of tourism, qualification of supply, strengthening of the cultural identity of the product, Sustainable development, Local development/economic development, Cluster and Increasing the consumption of local wine.

The articles analyzed contain information related to winemakers from different regions of the world, but serve as an initial tool to understand the motivations for the search of tourism as a strategy. The motivation that went the furthest among the samples studied was Marketing. The wineries seek to increase their options of selling channels, improve their relationship and better position their brand in the mind of the client who passes through the experience within the winery. More and more wineries are adding services to the sale of wine, bringing tourists to participate and get to know and how the wine is produced and the region where production takes place. In so doing, the customer gets more involved with a specific brand.

Since the service experience to the consumer is of great importance to the sale of the product, winemakers have begun to look for ways to meet their consumption requirements. The wine companies are inserting the consumers in the process and offering more benefits so that they choose their region as a tourist option. In addition, not only do winemakers benefit, but the region's culture is valued, generating income and employment.

Despite presenting the motivations that led the winemakers to adopt wine tourism, the analyzed articles did not present concrete data for these affirmations. Thus, a point to be highlighted for future studies is the measurement of the return on wine tourism investment. Many articles make comments on the high costs in infrastructure to offer wine tourism services, while not presenting return regarding sales, brand image, and economic development.

\section{References}

[1] M.H.S.G. Gimenes, C. Bizinelli, and F.C. Manosso, "Enoturismo E Atividades Complementares: Estratégias Para a Maximização Da Experiência Tur'łstica," p. 1, 2012

[2] M.H. Kunc, Int. J. Wine Bus. Res. 21, 325 (2009)

[3] S.K. Da Cunha, J.C. Da Cunha, Rev. Adm. Contemp. 9, 1 (2005)

[4] H. Tonini, "Estado e Turismo: Políticas Públicas e Enoturismo No Vale Dos Vinhedos (Brazil)" 6, 213 (2007)

[5] M.S. Guerra Ashton, V. Valduga, E.L. Tomazzoni, Investig. Turísticas 10, 90 (2015)

[6] D. Getz, G. Brown, Tour. Manag. 27, 146 (2006)

[7] A.V. Barquero, Desenvolvimento Endógeno em Tempos de Globalização - autografado (Porto Alegre: UFRGS/FEE, 2001)

[8] C.M. Hall, L. Sharples, N. Macionis, Wine Tourism Around the World: Development Management and Markets (Elsevier Ltd, 2004)

[9] V. Valduga, Caxias do Sul, 0-115 (2007)

[10] E.T. Byrd, B. Canziani, Y.-C. (Jerrie) Hsieh, K. Debbage, S. Sonmez, Tour. Manag. 52, 19 (2016)

[11] L. Tach, "Trends in wine tourism.” 2007

[12] S. Xu, C. Barbieri, D. Anderson, Y.-F. Leung, S. Rozier-Rich, Tour. Manag. 55, 276 (2016)

[13] A.D. Sánchez, M. de la Cruz Del Río Rama, J.Á. García, Eur. Res. Manag. Bus. Econ. 23, 8 (2017)

[14] M. Beverland, Int. J. Wine Mark. 10, 24 (1998)

[15] P.W. Binfare, P.L. de A. Galvão, C.A.T. Castro, PASOS. Rev. Tur. y Patrim. Cult. 14, 1217 (2016)

[16] D.M. De Oliveira, A. Ferreira, C. Filho, "City, architecture and wine: Wine tourism in the," 03026 (2016)

[17] S.S. Flores, C.V.S. Farias, G. Andrade, M.T. Russi, BIO Web Conf. 7, 03024 (2016)

[18] G. Carrà, M. Mariani, I. Radić, I. Peri, Agric. Agric. Sci. Procedia 8, 706 (2016)

[19] F.M. Olivieri, A. Giraldi, Almatourism J. Tour. Cult. Territ. Dev. 6, 11 (2015)

[20] E. Lemmi, M. Siena Tangheroni, Almatourism J. Tour. Cult. Territ. Dev. 7, 79 (2015)

[21] J.B. de Freitas, J.C. Martin, C. Roman, PASOS. Rev. Tur. y Patrim. Cult. 15, 341 (2017)

[22] J.J.P. Tabasco, M. del C.C. Ruiz, Á.R.R. Pulpón, "Heritage, vineyard and tourism: specific resources 
to innovate the territorial development of castilla-la mancha Julio José Plaza Tabasco", 719 (2017)

[23] G.N. Marques, J.M. Marques, Rosa dos Vent. 9, 107 (2017)

[24] A. Bencivenga, P.D. Vollaro, F. Forte, A.M. Giampietro, A. Percoco, Agric. Agric. Sci. Procedia 8, 176 (2016)
[25] M.L.G.S. José, "Wine tourism and sustainable environments", 193 (2017)

[26] A.M. Puche, F.J.M. Yago, Cuad. Tur. 38, 263 (2016)

[27] L.M. Ruiz, A.V.R. Vega, Investig. Turísticas 12, 73 (2016)

[28] J. Hudelson, SHS Web Conf. 01020 (2014) 